Vol. 13 (2004): 163-169.

Research note

\title{
Intra-plant variation for progress of cell division in developing oat grains: a preliminary study
}

\author{
Ari Rajala and Pirjo Peltonen-Sainio \\ MTT Agrifood Research Finland, Plant Production Research, FIN-31600 Jokioinen, Finland, \\ e-mail:ari.rajala@mtt.fi
}

\begin{abstract}
Development of an oat panicle proceeds from the uppermost terminal spikelet downward to the base of the panicle. The intra-panicle variation in development is likely to influence potential grain size. This may result from differences in activity and duration of the cell division phase, vascular transport capacity, duration of filling period and/or hormonal balance. In this preliminary survey we studied intra-panicle variation in pollination (when clusters of pollen were visibly attached to stigmatic branches) of florets and cell division in developing grains immediately after pollination of the oat cultivars Belinda and Fiia. We found substantial intra-panicle variation for both traits. The highest cell number was found in the uppermost, most advanced, primary grain, while secondary grains tended to have fewer cells compared with their counterpart primary grains irrespective of their position. Results of an additional experiment indicated that death of the primary floret in the conventional oat cultivar Virma prior to pollination, resulted in higher weight of secondary grain, though this never equalled that of the primary counterpart. This limited growth capacity may partly result from lower cell number. These results encourage us to continue with experiments on the contribution of groat cell number to sink strength and grain-filling capacity.
\end{abstract}

Key words: Avena sativa L., cells, pollination, filling period, naked oat, position, grain

\section{Introduction}

The oat inflorescence differs from that of other small-grain cereals in being a panicle rather than a spike. The development of the panicle proceeds from the uppermost terminal spikelet downward to the base of the panicle (Bonnett 1961a, Afors et al. 1988, Peltonen-Sainio and Pekkala 1993). Hence, the developmental stages of spikelets are likely to differ greatly within the panicle. According to Bonnett (1961a) the spikelet initia- 


\section{Rajala, A. \& Peltonen-Sainio, P. Intra-plant variation in developing oat grains}

tion phase continued for about 18 days to reach the basal parts of the panicle. When the last spikelets were set, the terminal floret was likely to be at an advanced developmental stage (Bonnett 1961a). Whether this intra-panicle variation in development rate remains similar throughout the duration of the panicle formation, and also at post-anthesis phases, seem not to be documented.

The position of the spikelet in the panicle and the floret in the spikelet contributes to sink capacity of the grain and determine thereby its potential grain weight (Bonnett 1961a, Youngs and Shands 1974, Housley and Peterson 1982, Tibelius and Klinck 1987; Doehlert et al. 2002), which is realised at varying degree depending (strongly) on growing conditions at grain-filling period. There are several, possibly interacting, factors contributing to the variation in grain weight. It may result from intra-panicle and intra-spikelet differences in development rate and time of pollination that are reflected in duration of grain-filling period (Bonnett 1961a, Tibelius and Klinck 1987), vascular transport capacity (Hanif and Langer 1972, shown in wheat; Housley and Peterson 1982), cell division rate and duration of developing grains as shown for wheat (Brocklehurst 1977, Radley 1978), and/or hormonal balance as shown for barley and maize (Michael and Seiler-Kelbitch 1972, Mounler et al. 1980, Myers et al. 1990, Ober et al. 1991).

Within each spikelet, the primary floret that develops into a primary grain is at more advanced development stage compared to that of secondary florets (Youngs and Shands 1974, Tibelius and Klinck 1987). Similarly, growth of primary grain exceeds growth of secondary and tertiary grains (Youngs and Shands 1974, Tibelius and Klinck 1987, Doehlert et al. 2002). In fact, the single kernel weight of primary grain seems to be dependent on number of florets in spikelet. Primary grain of three-floret spikelet was the heaviest, followed by the primary grain of twofloret spikelet and single-floret primary grain (Doehlert et al. 2002). This indicates stronger sink demand and/or better vascular transport capacity of multi-floral spikelets and further- more, a strong primary grain dominance over secondary and tertiary grains. Dissecting out primary grains and at various stages secondary grains, caused a marked increase in weights of the remaining secondary grains. However, the potential grain weight of remaining secondary grains appeared restricted as they constantly failed to reach the weight of primary grains recorded from intact control panicles (Tibelius and Klinck 1987). This limited capacity of secondary grains to fill - even when improved assimilate availability is likely to follow from absence of the primary grain - may result from limitations in grain expansion due to restricting hulls, lemma and palea (Tibelius and Klinck 1987), and/or limitations in assimilate transport capacity as for wheat (Hanif and Langer 1972).

With this preliminary study, we aimed to record the variation in progress of pollination and subsequent cell division in primary and secondary florets and grains at different positions in the oat panicle (in two oat cultivars grown in southern Finland).

\section{Material and methods}

Two oat cultivars, Belinda and Fiia were selected for this study, as their mean single grain weight differed, being $41.1 \mathrm{mg}(\mathrm{SE} \pm 0.4)$ in Belinda and $35.8 \mathrm{mg}(\mathrm{SE} \pm 0.4)$ in Fiia when grown in long-term official variety trials (Kangas et al. 2003). They were grown in the Finnish official variety trial at Jokioinen, MTT Agrifood Research Finland in 2002. The date of pollination of the uppermost primary floret was recorded (Waddington et al. 1983) and head samples (5 heads) were collected 1-2 (depending on cultivar), 4-5, 7-8, and 11-12 days after pollination (DAP). Pollination was marked to occur when stigmas were wide open and clusters of pollen were visibly attached to stigmatic branches (Waddington et al. 1983). Panicles were fixed for 24 hours in acetic acid/ethanol (75/25 in vol/ vol) and thereafter stored in $70 \%$ ethanol under 
cool and dark conditions. Progress of pollination in different positions of the panicle was determined and the cell numbers were counted in pollinated grains.

Cell number of the developing grains was determined according to the slightly modified procedure introduced by Tuberosa et al. (1992). As the cell number counting was started right after the pollination of the uppermost primary grain (1 DAP onwards), the developing grains were so small that only glumes, palea and lemma were removed. Hence, we did not determine endosperm cell number, but the cell number of the whole groat. The dehulling procedure was carried out similarly throughout the counting period to enable comparison among different counting dates.

The individual panicles, stored in ethanol, were rinsed three times with deionised water and placed in deionised water for $5 \mathrm{~min}$ at room temperature. After removal of glumes, paleas and lemmas, groats were placed in $1 \mathrm{~N} \mathrm{HCL}$ and kept for $30 \mathrm{~min}$ on ice and $20 \mathrm{~min}$ at $60^{\circ} \mathrm{C}$ in a water bath. After three rinses with deionised water, samples were placed in Feulgen's reagent (Schiff) for $4 \mathrm{~h}$ in the dark at room temperature. After stain removal with three rinses, samples were macerated in a sodium-acetate-buffered $(\mathrm{pH}$ 4.8) solution of cellulase (Onozuka R10) of 5\% (1-4 DAP) and 10\% (8-12 DAP) for $17 \mathrm{~h}$ at $37^{\circ} \mathrm{C}$. Stained cell nuclei were visually counted under microscope $(50 \times$ magnification $)$ in a haemocytometer (Fuchs-Rosenthal). Numbers of nuclei in four separate blocks of squares (total of 64 squares) were counted from two separate sub-samples of a single grain.

An additional experiment was arranged in the greenhouse at Viikki experimental farm, University of Helsinki, with the conventional oat cultivar Virma and the naked cultivar Rhiannon. 15 viable seeds of each cultivar were pre-germinated and normally developed seedlings were placed into $7.5 \mathrm{~L}$ pots containing a mixture of peat and vermiculite (1:1). Seedlings were thinned to ten per pot following emergence. Photoperiod was set at $17 \mathrm{hrs}$ and the minimum temperature to $20^{\circ} \mathrm{C}$. Liquid fertilizer $(6.4-5-26 \mathrm{~N}-\mathrm{P}-\mathrm{K})$ was ap- plied during watering at $0.4 \%(\mathrm{v}: \mathrm{v})$ at every other watering. Two trials with 9 and 8 replicates were arranged with pots set in a completely random design. They were surrounded by additional pots to reduce growth-promoting edge effects. Close to heading, all the panicles were trimmed to include only the 15 uppermost, most advanced spikelets. Both stamens and pistil of either primary or secondary florets were lethally damaged with tweezers. No floret manipulation was conducted on the control panicles, but they were also trimmed to only 15 spikelets. When plants matured, panicles from different treatments were gathered and threshed by hand and primary and secondary grains weighed. Mean values and their standard errors for single grain weights (SGW) were calculated.

\section{Results and discussion}

In both cultivars progress of pollination from the uppermost primary floret towards the basal spikelets took more than 11 to 12 days, corresponding to $>100$ degree days $\left({ }^{\circ} \mathrm{C} \mathrm{dd}, 5^{\circ} \mathrm{C}\right.$ as the base temperature), i.e., longer than the period during which the panicle samples were gathered (Fig. 1). In 'Fiia' only two secondary florets and in 'Belinda' all the florets in the two most basal branches failed to reach pollination prior to termination of sampling. Occurance of tertiary grains was very random and modest in both cultivars in 2002, and hence, their development was omitted. According to Bonnett (1961b), the period between the first and the last floret being pollinated in an oat panicle took seven to ten days in the Midwest USA. Our result is surprising in that development of oat in general is enhanced by long days at high latitudes (Peltonen-Sainio 1999). For example, Peltonen-Sainio and Pekkala (1993) indicated that, under the growing conditions of southern Finland, the whole pre-anthesis reproductive phase required some $330^{\circ} \mathrm{C}$ dd depending on oat cultivar. Relative to this, the recorded differences in develop- 
Rajala, A. \& Peltonen-Sainio, P. Intra-plant variation in developing oat grains

ment within the panicle are rather large. The 2002 growing season was exceptionally warm, but following panicle emergence temperature was close to the long-term average (1971-2000). The uppermost primary floret was always the first to be pollinated (Fig. 1). Thereafter pollination proceeded from the outermost spikelets of the second and third branches towards the basal parts of each branch. Within each spikelet, the primary floret was pollinated without exception prior to the secondary one.

The long intra-panicle pollination period recorded in this study exposed the grains in different branches of the developing panicle to varying, possibly even contrasting growing conditions and some of them may have faced temporary stresses during their critical developmental stages that the spikelets at more distant positions were not exposed to. This suggests that the grain filling capacity, grain-filling rate and ripening may vary considerably depending on the spikelet and grain position. This may have an effect on homogeneity of the grain yield, i.e. single kernel weight distribution in the panicle. Doehlert et al. (2002) ranked the factors affecting kernel weight in oat grown in Mid-West USA, finding kernel type and genotype more dominating than environment and kernel position on the panicle. Although, growing conditions during grain filling have definite effect on kernel weight, the effect on homogeneity of kernel weight may be more complex (Doehlert et al. 2002).

When studying intra-panicle variation in cell division at early post-heading, we found that the uppermost primary floret that was pollinated first also had the highest cell number in both culti-
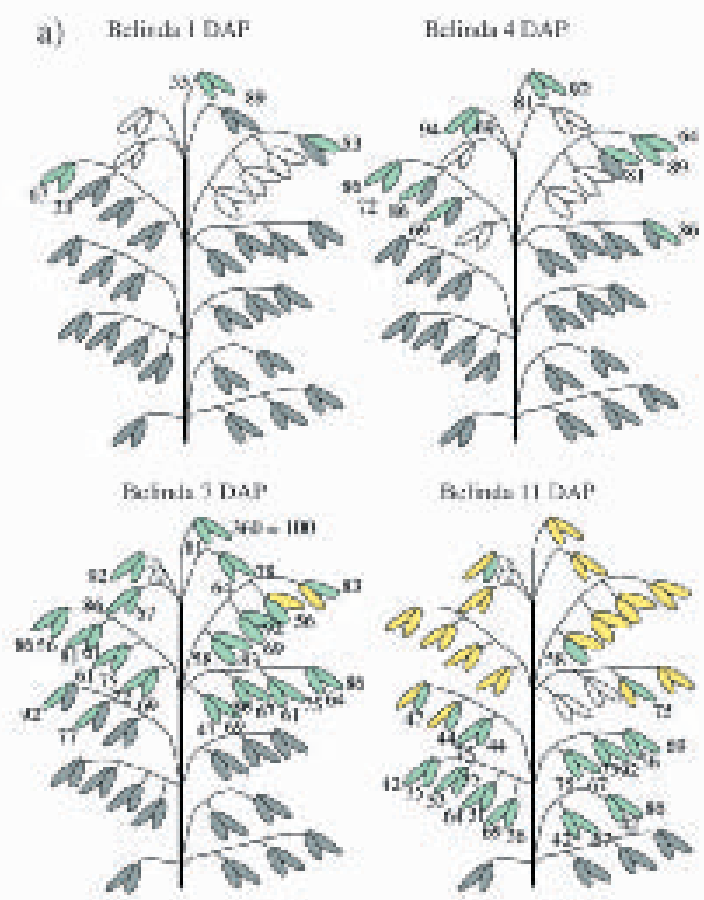
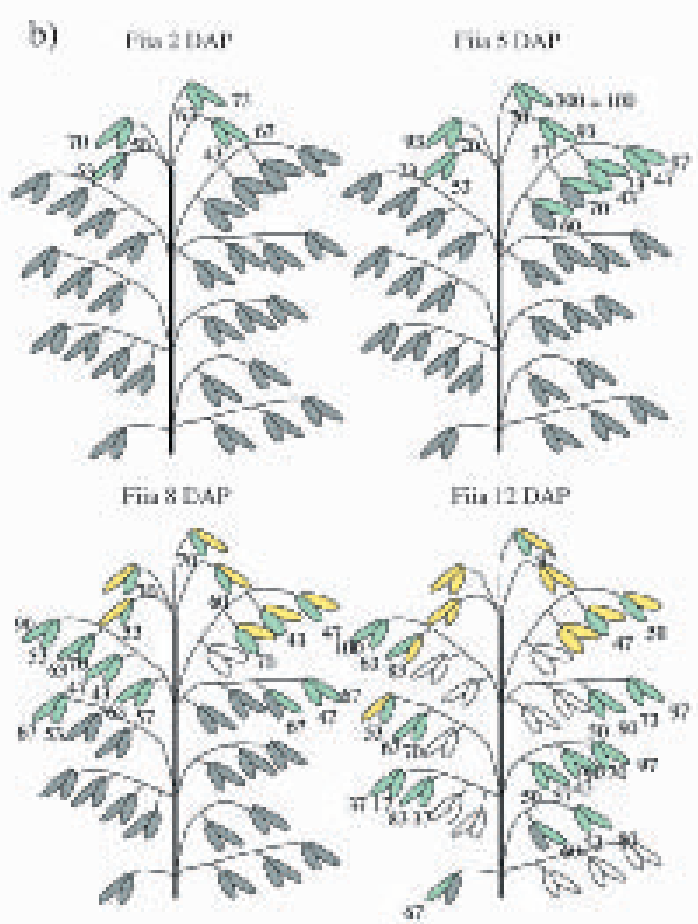

Fig. 1. Number of cells relative to that of the primary grain in the uppermost terminal spikelet of oat cultivars Belinda (a) and Fiia (b) at four different dates after pollination (DAP). In Belinda 100 refers to cell number of 360,000 per groat (at 7 DAP), while in Fiia the figure is 300,000 cells per groat (at 5 DAP). Colour indications of the figure: grey - non-pollinated, green - pollinated, yellow - starch accumulated and declined cell numbers, transparent - no spikelet existed in studied panicle. 
Vol. 13 (2004): 163-169.

Table 1. Weight of primary and secondary grains of conventional oat cultivar Virma and naked oat cultivar Rhiannon when either secondary (A) or primary (B) counterpart grain was removed prior to pollination [compared with intact panicles $(\mathrm{C})]$. Standard errors of means are shown in parentheses.

\begin{tabular}{|c|c|c|c|c|c|c|c|c|c|}
\hline \multirow[t]{2}{*}{ Cultivar } & \multirow[t]{2}{*}{ Trial } & $\begin{array}{r}\text { A } \\
\text { Primary }\end{array}$ & A & \multicolumn{2}{|c|}{$\begin{array}{c}\text { B } \\
\text { Secondary grain }\end{array}$} & \multicolumn{2}{|c|}{$\begin{array}{c}\text { C } \\
\text { Primary grain }\end{array}$} & \multicolumn{2}{|c|}{$\begin{array}{c}\mathrm{C} \\
\text { Secondary grain }\end{array}$} \\
\hline & & SGW (mg) & (SE) & SGW (mg) & (SE) & $\mathrm{SGW}(\mathrm{mg})$ & (SE) & SGW (mg) & (SE) \\
\hline Virma & 1 & 39.3 & $(0.74)$ & 26.6 & (2.17) & 35.5 & $(0.98)$ & 22.0 & $(0.79)$ \\
\hline Virma & 2 & 35.3 & $(0.56)$ & 24.8 & $(0.98)$ & 33.9 & $(0.64)$ & 20.3 & $(0.96)$ \\
\hline Rhiannon & 1 & 28.0 & $(0.98)$ & 26.8 & $(0.59)$ & 32.2 & $(0.94)$ & 28.1 & $(0.68)$ \\
\hline Rhiannon & 2 & 25.5 & $(0.60)$ & 24.3 & $(0.58)$ & 28.9 & $(0.92)$ & 25.2 & $(0.60)$ \\
\hline
\end{tabular}

SGW single grain weight, SE standard error

vars. The outermost terminal primary grains of lower branches had almost equal maximum cell numbers when compared with the uppermost primary grain (Fig. 1). Even though, the cell number calculations were based on only one individual panicle in time, and therefore no statistical comparison could be made, Belinda constantly, expressed higher cell number compared to Fiia as did the primary grains, in most cases, compared to secondary grains in both cultivars (Fig. 1). The maximum cell number of the uppermost primary grain reached about 360,000 in 'Belinda' and 300,000 in 'Fiia'. Subsequently accumulation of starch interfered with the counting to the extent that it was stopped.

As the single groat weight of cultivars Belinda and Fiia were $27.8 \mathrm{mg}$ and $23.1 \mathrm{mg}$ in this study and in the long-term variety trial $31.0 \mathrm{mg}$ (SE 0.4) and $27.8 \mathrm{mg}$ (SE 0.5), respectively. Recorded higher cell number in Belinda could indicate better grain filling capacity, as there are indications that endosperm cell number potentially associate with kernel weight as shown in wheat (Brocklehurst 1977, Radley 1978). Furthermore, the position of the panicle with highest cell number in our study (Fig. 1) also tended to produce the largest and heaviest grains in the study of Youngs and Shands (1974). Results from an additional experiment in the greenhouse with the conventional oat cultivar Virma and the naked Rhiannon further supported the finding that secondary grains are consistently lighter (Table 1), also in agreement with our preliminary finding on lower cell number. Irrespective of whether the primary or secondary floret was sterilised, there was $10 \%$ boost in the remaining primary grain and a $17 \%$ boost in the remaining secondary grain in growth of conventional oat (Table 1). This is in agreement with the results of Tibelius and Klinck (1987). However, in the naked cultivar there was no enhancement of growth of the remaining grain when a floret from the same spikelet was terminated (Table 1). The reason for this is not apparent as the sterilisation procedure was unlikely to have been more difficult for the naked oat panicle. Hull induced restriction of grain enlargement has been postulated earlier for conventional oat (Tibelius and Klinck 1987). The palea and lemma of naked oat are both thin and papery (Ougham et al. 1996) and therefore this is not an obvious explanation for our finding. Speculatively, radically reduced grain number in panicle resulted in insufficient sink demand to sustain active assimilation and consequently feedback inhibition caused overall reduction in photosynthesis and in grain filling.

Even though the weight of secondary grain was increased, it never reached the size of primary grain when the primary grain was prevented from developing by damaging the floret. Potential weight of secondary grain appears to be 
Rajala, A. \& Peltonen-Sainio, P. Intra-plant variation in developing oat grains

restricted (Table 1), as also noted by Tibelius and Klinck (1987). This is supported by the finding that secondary grain had a lower cell number than its counterpart primary grain. Youngs and Shands (1974) and Doehlert et al. (2002) reported higher proportional groat weight for secondary than primary grain. This implicates either lighter hulls or more complete grain filling of secondary grains compared with the primary grains.

In conclusion, our preliminary study indicated substantial intra-panicle variation in progress of pollination and cell division in oat cultivars grown in southern Finland. Our intention is to design additional experiments based on these preliminary data. Further studies will be directed particularly to the contribution that differences in floret and grain development make to determination of grain weight and grain-filling rate at different positions in the panicle and spikelets. Intact and manipulated panicles will be used and the sampling period will be extended beyond the one used here.

\section{References}

Åfors, M., Ohlander, L. \& Stendahl, F. 1988. Stråsädens utveckling I. En literaturstudie och beskrivning av en skala för bestämning av stråsädens ax-respektive vippanlag. Sveriges Lantbruksuniversitet. Institution för växtodlingslärä. Uppsala. 75 p.

Bonnett, O.T. 1961a. The oat plant: Its histology and development. Bulletin 672. University of Illinois. Agricultural Experiment Station. 112 p.

Bonnett, O.T. 1961b. Morphology and development. In: Coffman, F.A. (ed.). Oats and oat improvement. American Society of Agronomy, Madison, WI. p. 41-74.

Brocklehurst, P.A. 1977. Factors controlling grain weight in wheat. Nature 266: 348-349.

Doehlert, D.C., McMullen, M.S. \& Riveland, N.R. 2002. Sources of variation in oat kernel size. Cereal Chemistry 79, 4: 528-534.

Hanif, M. \& Langer, R.H.M. 1972. The vascular system of the spikelet in wheat (Triticum aestivum). Annals of Botany 36: 721-727.

Home, S., Wilhelmson, A., Tammisola, J. \& Husman, J.
1997. Natural variation among barley kernels. Journal of American Society of Brewing Chemists 55: 4751.

Housley, T.L. \& Peterson, D.M. 1982. Oat stem vascular size in relation to kernel number and weight. I. Controlled environment. Crop Science 22: 259-263.

Kangas, A., Laine, A., Niskanen, M., Salo, Y., Vuorinen, M., Jauhiainen, L. \& Mäkelä, L. 2003. Results of official variety trials 1995-2002. Agrifood Research Working papers 29. $235 \mathrm{p}$.

Michael, G. \& Seiler-Kelbitch, H. 1972. Cytokinin content and kernel size of barley grains as affected by environment and genetic factors. Crop Science 12: 162165.

Mounler, M., Bangerth, F. \& Story, V. 1980. Gibberellinlike substances and indole type auxins in developing grains of normal and high-lysine genotypes of barley. Physiologia Plantarum 48: 568-573.

Myers, P., Setter, T., Madison, J. \& Thompson, J. 1990. Abscisic acid inhibition of endosperm cell division in cultured maize kernels. Plant Physiology 94: 13301336.

Ober, E., Setter, T., Madison, J., Thompson, J. \& Shapiro, P. 1991. Influence of water deficit on maize endosperm development. Enzyme activities and RNA transcripts of starch and zein synthesis, cell division and ABA. Plant Physiology 97: 154-164.

Ougham, H.J., Lapitova, G. \& Valentine, J. 1996. Morphological and biochemical characterization of spikelet development in naked oats (Avena sativa). New Phytologist 134: 5-12.

Peltonen-Sainio, P. 1999. Growth and development of oat with special reference to source-sink interaction and productivity. In: Smith, D.L. \& Hamel, C. (eds.). Crop yield, physiology and processes. Springer-Verlag, Berlin, Germany. p. 39-66.

Peltonen-Sainio, P. \& Pekkala, T. 1993. Numeric codes for developmental stages of oat apex in the growing conditions of southern Finland. Agricultural Science in Finland 2: 329-336.

Radley, M. 1978. Factors affecting grain enlargement in wheat. Journal of Experimental Botany 29: 918-934.

Tibelius, A. \& Klinck, H.R. 1987. Effects of artificial reduction in panicle size on weight of secondary seeds in oats (Avena sativa L.). Canadian Journal of Plant Science 67: 621-628.

Tuberosa, R., Sanguineti, M.C., Stefanelli, S. \& Quarrie, S. 1992. Number of endosperm cells and endosperm abscisic acid content in relation to kernel weight in four barley genotypes. European Journal of Agronomy 1: 125-132.

Waddington, S.R., Cartwright, P.M. \& Wall, P.C. 1983. A quantitative scale of spike initiation and pistil development in barley and wheat. Annals of Botany 51: 119-130.

Youngs, V.L. \& Shands, H.L. 1974. Variation in oat kernel characteristics within the panicle. Crop Science 14: 578-580. 
Vol. 13 (2004): 163-169.

\title{
SELOSTUS
}

\section{Esitutkimus kauran röyhyn sisäisestä vaihtelusta jyvän täyttymisen käynnistyessä}

\author{
Ari Rajala ja Pirjo Peltonen-Sainio \\ MTT (Maa- ja elintarviketalouden tutkimuskeskus)
}

Kauran röyhy kehittyy ylhäältä alaspäin, joten ensimmäisenä erilaistuva päätetähkylä on aina pisimmälle kehittynyt. Tämän huomattavan röyhyn sisäisen vaihtelun takia eri jyvillä on todennäköisesti hyvin erilaiset täyttymisedellytykset. Tutkimme alustavassa kokeessa kahden kauralajikkeen (Belinda ja Fiia) kukkien pölyttymistä eri osissa röyhyä ja määritimme toistomittauksin kunkin jyväaiheen solunjakautumisen etenemistä.

Havaitsimme, että pölyttyminen, solujen jakaantuminen ja maksimi solumäärä vaihtelivat huomattavasti röyhyn osasta toiseen. Koko röyhyn pölyttymiseen kului yli kymmenen vuorokautta siitä, kun kehittynein röyhyn päätetähkylä oli pölyttynyt. Tässä jyvässä oli myös suurin solumäärä. Sisäjyvissä oli järjestelmällisesti vähemmän soluja kuin ulkojyvissä. Lisäkokeet osoittivat, että ulkokukan tuhoaminen ennen pölyttymistä lisäsi sisäjyvän painoa huomattavasti. Sisäjyvä ei kuitenkaan tässäkään tapauksessa painanut yhtä paljon kuin koskemattomien kontrolliröyhyjen ulkojyvät. Sen sijaan paljasjyväisen kauran sisäjyvä ei tullut painavammaksi, vaikka ulkokukka tuhottiin.

Nämä alustavat tulokset rohkaisevat jatkamaan tutkimuksia ja rinnastamaan havaitut erot röyhyn eri osien kehittymisessä jyvän täyttymiseen, jyvän painoon sekä laatuvaihteluun. 